\title{
The Synergy of Islamic Da'wah and Madura Culture Programmes on Nada FM Sumenep Radio, Indonesia
}

\author{
ZAINAL ABIDIN ACHMAD \\ RACHMAH IDA \\ MUSTAIN \\ RONALD LUKENS-BULL \\ Universitas Airlangga, Indonesia
}

Universitas Pembangunan Nasional Veteran Jawa Timur, Indonesia

\begin{abstract}
Nada FM Sumenep radio is the only commercial radio in East Java that has successfully synergised Islamic religious programmes and Madurese culture in its broadcasts. Several things influenced that success. This includes a careful understanding of business opportunities, ingenuity in creating programmes that fit the needs of religious content for Sumenep residents, Islamic da'wah programme that is synergised with Madurese culture, and the support of communication technology (mediamorphosis). This qualitative research method uses virtual ethnography, where researchers conducted participant observation in the real and virtual world. The informants are one cultural leader, two programmers, one announcer, and three loyal listeners. This research explored the process of mediamorphosis, types of Islamic da'wah programmes, and Madurese cultural programmes, content, and the form of interaction among listeners and radio institutions in a networked society. The results showed that the form of mediamorphosis of Nada FM radio can be seen through the usage of streaming, Facebook, Twitter, Instagram, and WhatsApp. The aim of synergising content is to strengthen Islamic religious beliefs while maintaining Madurese culture. Connectivity in a networked society makes it easier to gain access to the radio content. Listeners prefer using WhatsApp as the media to express criticism. The ad suitability, chat duration, announcers' attitude, quality of sound and streaming, and the suitability of the $d a^{\prime}$ wah theme are also key reasons to the success of Nada FM Sumenep radio.
\end{abstract}

Keywords: Culture radio, da'wah radio, mediamorphosis, virtual ethnography, Indonesia.

\section{INTRODUCTION}

Nada FM Sumenep radio proves that Islamic religious education programmes with Madurese culture can be synergized in radio broadcast programmes. This synergy supports the research on the character of the Madurese in Sumenep, who are known to have an open attitude in combining Islamic teachings with cultural traditions (Rahem \& Abrari, 2019). Historical evidence of the entry of Islam in the Sumenep area showed that the Islamic religious figures who spread Islam in Madura carried out very peaceful acculturation between Madurese culture and Islam. Hence, it is not surprising that the Madurese ethnic group accepts Islam's presence with an open heart and mind. In this regard, it is essential to underline that Indonesia's people stereotypically and commonly recognise all Madurese as Muslim: to be a Madurese is to be a Muslim. Since Madurese people acknowledged Islam, it quickly increased and nurtured as a religion of the majority that inspires everyday life and culture (Siddiq, Epafras \& Husein, 2018). Islam is seen as both encouraging Madurese in being Muslim and to continue practicing Madurese culture. Islamic perpetuation within Madurese tradition has 
been retained in many aspect of people's lives, including language and literacy. There are many Arabic-absorptive words, names with references to Arabic names, familiarity with Arabic-Islamic expressions, and many art performances signifying cultural expressions of the Madurese rooted in Arabic-Islamic tradition (Bouvier, 2002).

There are three types of programmes designed on Radio Nada FM: Islamic da'wah programme, Madurese cultural programme, and Islamic da'wah programme mixed with Madurese culture. One example of a blended programme is called "Dogma: Dialog Agama (Religious Dialogue)." The broadcast contains Islamic religious education, delivered in the Madurese language, and the music broadcasted are Madurese songs. These blended programmes succeed in building listeners' loyalty and contributed a significant income through advertising (Achmad, 2019).

Synergy is an important concept that many advertisers apply in their media plans. Integrated Marketing Communications (IMC) emphasises the role of synergy, which arises when the combined effect of multiple activities exceeds the sum of their individual effects (Raman \& Naik, 2004). Synergy is a phenomenon in which the whole is not always exactly equal to the sum of the parts, but could be greater than, or lesser than that sum (Lesscher, Lobschat \& Verhoef, 2021; Schultz, Block \& Raman, 2012). In the context of this study, synergy in radio programming is done to help facilitate the community in a dialogue, by encouraging their participation through the radio station's various programmes and giving them a positive experience (Gaynor \& O'Brien, 2017). Radio provides a distinct benefit to those that participate by constituting a 'community within' the radio station while also building and consolidating the wider community by fostering connections and networks. The synergy emphasises on bringing culture and religion to the radio platform.

Besides having a robust Madurese cultural environment, this success is due to the support of communication technology. In the current convergence era, the ability to adapt to emerging communication technology becomes an essential requirement to support radio broadcasts (Achmad \& Ida, 2019). Communication technology platforms used to support Nada FM radio broadcasts include Facebook, streaming, Instagram, Twitter, and WhatsApp. The use of these platforms makes the relationship between institutions (director, station manager, programmers, producers, music director, creative teams, broadcasters) with listeners and advertisers closer.

\section{Nada FM}

Nada FM radio is the first commercial radio born on the island of Madura and has a long history as a da'wah and cultural radio station. One of the critical reasons for the establishment of Nada FM radio was the presence of government-owned radio, "Radio Republik Indonesia Sumenep" (RRI, Radio of the Republic of Indonesia), established in April 1968. Like all public radio stations, RRI cannot accept advertisements. Over time, Madura's economy grew but there was no commercial radio which the various industries could advertise on. Hence, the establishment of a commercial radio station in Madura helped local businesses to market their products and saw the local economy flourished.

Nada FM radio was officially established on July 23, 1971, and had the name "Radio Double One AM" with permission to use the AM frequency at $1440 \mathrm{kHz}$. As Sumenep's residents are committed to both an Islamic and a local cultural (Madurese) identity the radio programmes broadcasts news, religious education, culture, and entertainment, as part of their aim to serve Sumenep residents' needs. 
Managing a commercial radio business includes managing two different markets simultaneously, namely products and broadcast content aimed at the listeners' and advertiser's markets. This means, the commercial radio business' focus lies on the broadcast content and increasing the number of listeners. Evidently, it does not experience resource constraints in producing broadcast content (Singarimbun, Karlinah, Hidayat \& Darwis, 2019) as various events that occur in the community every day, can be considered as unlimited resources for radio. In addition, a commercial radio also produces cultural products that enrich cultural diversity (Mohammed, 2018). Thus, commercial radio can contribute to education and increase people's insight.

To get more advertisers, radio stations should carry out specific strategic steps that begin with determining segmentation to get the desired market. Segmentation is the selection of potential listeners as a basis for determining the programme to be broadcasted to meet the needs of the listener. A well-known management expert, Rhenald Kasali, argues that commercial radio must have sharp and clear target segments (Kasali, 1998). Radio should target by searching, choosing, determining, and reaching the target market (Boyd, 2000). Radio programmes, then, are delivered for listeners in the intended segment (Nelson-Field \& Riebe, 2011; Romeo \& Dick, 2005) which will ensure that the programme execution is accepted and liked by listeners (List, 2003). As asserted by Ferne (2007) an excellent radio programme is a programme that can meet the needs of listeners.

Commercial radio will undoubtedly get much support from loyal listeners if they can carry out these strategic steps well. More and more loyal listeners who support the programme will provide many benefits for the radio. Loyal listeners are a good market and can function as a very effective means of promotion (Oliver, 1999). Meanwhile, comfort listeners can form loyalty. The more comfortable they are, the stronger their loyalty will be.

Commercial radios are predicted to be able to continue to survive and win the competition if they aim at the listener's loyalty as a corporate goal (Hjarvard, 2008; Dia, 2003). Nada FM radio seeks to realise loyalty beyond a simple cognitive loyalty, namely conative loyalty -- the commitment of listeners to be willing to listen to radio broadcasts continuously -- and action loyalty -- listener's participate and voluntarily takes action to influence change in society (Myers, 2009).

Sumenep is a regency that has a Muslim population of $97.8 \%$ or $1,098,905$ of its $1,123,310$ residents. There are 361 Islamic boarding schools spread throughout the Sumenep region (Bappenas $\mathrm{RI}, 2016$ ). This composition shows the potential for a large number of radio listeners who need Islamic da'wah broadcasts. So far, Nada FM radio has fulfilled the Islamic missionary needs of Sumenep residents through its broadcast. However, the development of contemporary Islamic da'wah in Indonesia seems to influence changes in connectedness between listeners in remote Sumenep villages and Nada FM radio. The number of teachers of Islamic religion (Kyai, Nyai, Ustadz, and Ustadzah) are presenting prayers via YouTube, Facebook, and Instagram, arousing Sumenep residents' hopes to get Madurese-speaking Islamic da'wah from local teachers of the Islamic religion.

Da'wah programme listeners consider that listening to radio broadcasts through transistor radio devices is out of date. The mediamorphosis of broadcasting can be seen when Nada FM radio broadcasted its programmes through Facebook, Instagram, Twitter, YouTube and WhatsApp, all of which gives new enthusiasm for the people of Sumenep. The platform makes the relationship between listeners, broadcasters, and preachers more intimate, equal, and personal. This contradicts the reality faced by Madurese community's which has the 
tradition of pesantren (a form of Islamic education in Indonesia), that puts Kyai, Nyai, Ustadz, and Ustadzah in a very noble, honourable and untouchable position (Paisun, 2010).

However, the introduction of live streaming broadcasts via Facebook, has enabled people in Sumenep to have direct dialogues and jokes with Kyai, Nyai, Ustadz, and Ustadzah. Live streaming broadcasts via Facebook by Nada FM enabled listeners to be involved in a networked community structure. A new social structure that values listeners not only as consumers, but involves them as broadcast programme producers, seems to have emerged from this mediamorphosis. A simple example is in determining the theme of religious dialogue; producers and broadcasters involve listeners to determine the theme and determine the Kyai or Nyai, who deserves to be invited to speak on radio broadcasts. For this reason, this study aims to: 1) Map the mediamorphosis of broadcasts on Nada FM; 2) Describe radio programmes that combine Islamic da'wah with Madurese culture; 3 ) Describe the role of Nada FM and its listeners in delivering Islamic da'wah and preserving Madurese culture.

Mediamorphosis is a scientific term used to describe the way an organism or any of its parts undergoes change, to create a new word to describe the simultaneous changes taking place in the media world today (Achmad, Juwito, Candrasari, Ashfaq, 2021; Achmad \& Ida, 2019; Biagi, 2017; Nwammuo, 2011). Mediamorphosis refers to the transformation of communication media, as a result of the complex interplay of social and technological innovations, perceived needs and competitive and political pressures (Achmad \& Juwito, 2020; Alves, 2001; Loop, 1998)

\section{LITERATURE REVIEW}

A successful commercial radio is a radio that gets a significant income through advertising (Johansen, 2010; RadioCentre, 2013). That opinion is not entirely right or wrong. Many other factors are interrelated to each other in influencing income, including good broadcast programmes, a large number of listeners, having passionate managers, having creative employees, reliable broadcast technology, interactive listeners, the ability to change, qualified management, and a conducive socio-political climate (Achmad \& Ida, 2019; Nugroho et al., 2012; Sen, 2003). Among these factors, the most important is the ability of radio to change and adapt to the development of communication technology (Geller, 2011; Lacey, 2013; Jurriens, 2009; Kuyucu, 2016; Schmidt, 2012).

Nada FM has a uniqueness in synergising Islamic da'wah programmes with Madurese cultural programmes. This radio chooses that programming policy because it wants to approach its listeners through spiritual closeness (Al-hassan et al., 2011) and cultural closeness (Nguyen, 2008). These advantages are not possessed by other radios in Madura island, even in East Java Province. That is what makes it durable, enabling it to garner the most significant number of listeners on the island of Madura. In addition, with the support of mediamorphosis via Facebook, Instagram, and WhatsApp, listeners have an interactive and participatory role. That is, Nada FM gives listeners a chance to have a role in broadcasting, as witnesses to various events through interviews, news coverage, dialogues, and talk shows (Benjamin, 2003).

Nada FM is one of ten commercial radio stations in East Java, which has a cultural radio positioning (KPID Jawa Timur, 2017; PRSSNI Jatim, n.d.). Many commercial radio stations choose to position news and pop entertainment radio in the middle of the crucial popular culture trend. Some news and pop commercial radio stations in East Java went bankrupt, and some chose to switch formats (Achmad \& Alamiyah, 2015). Interestingly, Nada FM, which 
broadcasts $d a^{\prime}$ wah and local culture programmes, still receives significant advertising revenue as it reaches many listeners.

Mediamorphosis of Nada FM in broadcasting $d a^{\prime}$ wah and local culture programmes gives advantages in understanding Islam's religion and strengthens Madurese cultural identity. The strengthening of identity as cultural radio (Bosch, 2014) using the Madurese language, songs with Madurese lyrics in Islamic da'wah broadcasts, is a prominent feature in the broadcast programme blending on Nada FM radio.

The researchers propose that the process of mediamorphosis on Nada FM changes the radio listeners' characteristics of Sumenep residents, who are predominantly Muslim. Those who were once invisible, kept to themselves and communicated passively now have changed to be seen and heard, have an open identity, communicate interactively, and in a participatory manner (Bonini \& Monclús, 2015). We posit that radio listeners involve themselves through participation on Facebook, Instagram, and WhatsApp because they are members of a networked community in the virtual world (Baltzis, 2004; Cordeiro, 2012; Geller, 2011; Martín, 2016; Priestman, 2001). Listeners then live in both the real and virtual worlds. One of the effects of this two-world relation is the changing value of radio listeners who can no longer be thought of as mere consumers and commodities. They are valuable as participants and radio programmers (Achmad, 2020; Al-hassan et al., 2011; Kuyucu, 2016; Norbier, 2012; Essential Research, 2013).

\section{METHODOLOGY}

This qualitative research uses a virtual ethnography method. The reason for choosing virtual ethnography is to examine the relationship between listeners and radio workers in the real world and the virtual world. A critical feature in virtual ethnography research is its ability to identify the virtual world (Achmad \& Ida, 2018). In this case, the information obtained from the virtual ethnography can help explain the mediamorphosis process and unpack the relations between listeners and radio institutions. To maximise the potential of a virtual ethnographic research, researchers conducted participant observation techniques as members of a networked society, over a duration and carefully considered the data and analysis needed (Parks \& Floyd, 1996).

As a participant, researchers carry out the following activities: (1) observe studio life and engage in broadcast activities, (2) observe and engage in the interaction between listeners and radio employees, (3) observe the social media accounts of the speakers and engage themselves in communication on social media (Facebook, WhatsApp and Instagram) with listeners and radio workers. This study carried out participatory involvement for one year in the virtual world and physically for 20 days in Sumenep.

The reason for choosing the participant observation technique is because it allows the researchers to understand the entire social context, get direct experience, see things that are not observed by others, find information that is sensitive or closed, find things outside the subject's perception and collect rich data through personal impressions (Fine, 2003).

This research collected data through (1) ethnographic notes and documents, (2) indepth interviews, and (3) secondary sources. This research obtained ethnographic records and documents through active interaction and participation on: Nada FM official streaming page, Nada FM official Facebook account, the official Instagram account of Nada FM, the official twitter account of Nada FM, and the WhatsApp group "Penikmat NADA FM" 
(consisting of managers, programmers, marketing, broadcasters, cultural leaders, community leaders, bureaucrats, and loyal listeners).

Researchers also communicated with and observed the informants' Facebook accounts, including those of Ibnu Hajar (Madurese cultural leader), Ahmad Jailani (programmer), Ridwan (programmer), Merry Rafika (announcer), Sudap Hafiz (listener), Eka Rizka (listener) and Rikso (listener). However, in Rikso's case, his Facebook account was not looked at because he does not have one.

The number of informants in this study is based on the need to compare the experiences of informants, with consideration of the differences in age, occupation, choice of interaction channels, and length of time visiting the virtual world (Achmad \& Ida, 2018; Hair \& Clark, 2003; Hine, 2000, 2005; Schaap, 2002).

In this study, researchers carried out several stages of virtual ethnography. The first step was to identify the social groups to enter and become a part of. Researchers entered the WhatsApp group and followed Nada FM's Facebook and Instagram account with the administrators' approval. In the second step, after becoming part of the community, researchers explain the research's purpose, the subject under study, and offer research benefits. The third step was to contact the informants through participant observation - the direct involvement of researchers in the virtual world for the depth of appropriate information. In the fourth step, researchers conducted in-depth interviews in a dialogical and interactive manner. The researchers explored the hidden meaning with the subject, verifying each understanding before giving further analysis, and giving criticism. This ethnographic interview process considers "sharing experiences' (Guest, Namey \& Mitchell, 2013; Sapsford \& Jupp, 2006).

The researcher gained access in several ways. First, the broadcasters involved the researchers in on-air broadcasts on Nada FM. They introduced the researchers to listeners. Second, the broadcasters and the listeners involved the researchers in off-air activities: meeting with kyai or ustadz and santri at recitals, culturists at traditional art performances and advertisers at product promotion activities. The entry and access to the virtual community of Nada FM (WhatsApp group and a Facebook fan page) help researchers to establish communication with certain people. They are programmers, broadcasters, or loyal listeners who become the admin of the virtual community. Requirements as admins included being very active in social media, having excellent communication skills, good temperament, and on relationships with Nada FM.

\section{RESULTS AND DISCUSSION}

Since the enactment of the Broadcasting Law No. 32 of 2002, many commercial radios in Indonesia have switched from AM to FM. On October 16, 2004, Radio Double One AM changed to Radio Nada FM to use the FM frequency at $102.9 \mathrm{MHz}$. Since switching to FM, Nada FM is known for having clear audio quality and reaching Madura's island. This has led to Nada FM having the most number of listeners in Madura.

In 2004, Nada FM radio weighed heavily on Islamic music and Madurese music. The portion is $50 \%$ Indonesian music, $30 \%$ western music and $20 \%$ Madurese and Islamic music. Since 2009, Madurese songs have been given up to $40 \%$ of air time, and the rest is for Indonesian, Arabic, and Western songs. Every opening and closing programme uses greetings according to Islamic norms with the accompaniment of Saronen (trumpet-like instruments), in order to strengthen the identity as Islamic da'wah and Madurese cultural radio. 
The type of music that is currently popular with the people of Sumenep is UI-Daul music. Percussion from the Middle East (drum) combined with a makeshift musical instrument influenced UI-Daul music. This music was originally played to wake people up during the Sahur meal in Ramadhan and during Takbiran (Tamimi, 2019). Nada FM currently has the most portion of Madurese dangdut songs, with various additional variants of instruments, including collaboration with hadrah (Arab-style drum ensemble), saronen, and patrol (a percussion instrument made from bamboo). In the last three years, there has been a trend in Madura to change pop or dangdut songs with Javanese and Indonesian lyrics into Madurese lyrics.

Nada FM made improvements in the news section by adding personnel to the reporter's position for the news coverage programme because, at that time, no radio broadcasted news and local issues about Sumenep and the surrounding area. It also updates the supporting broadcast technology, such as recording studios, editing computers, mixers, on-air computers, and others. The new management was committed to promoting education for the Sumenep residents despite the status of commercial radio. For this reason, all its programmes emphasise the identity of Islamic $d a^{\prime} w a h$ and Madurese culture.

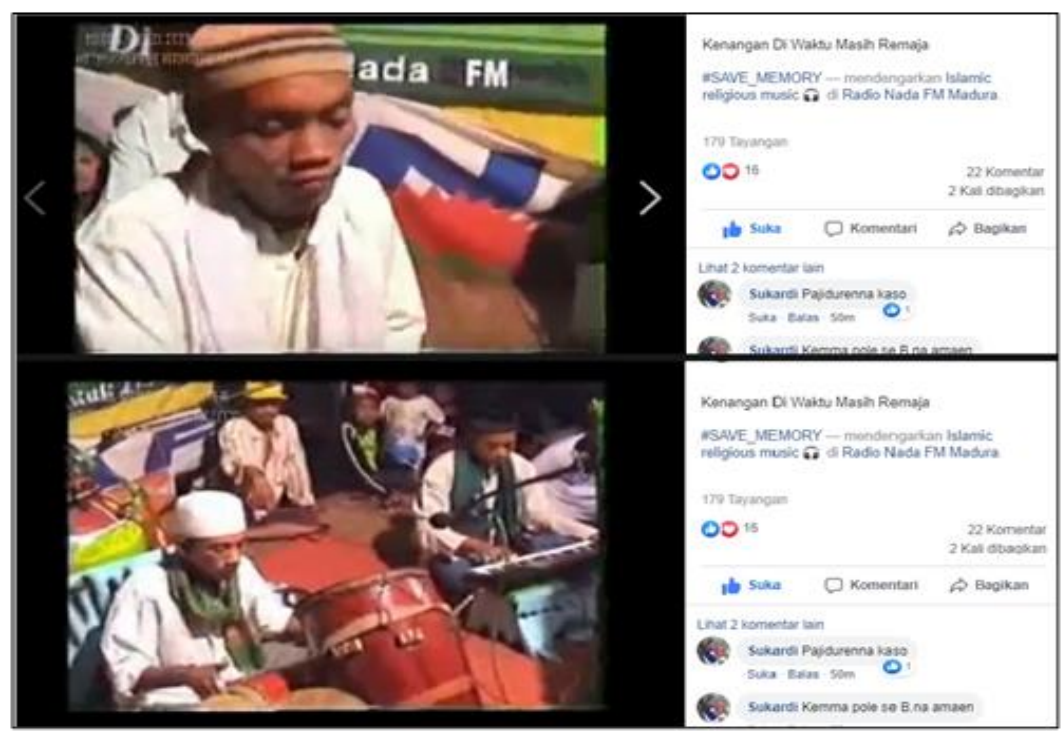

Figure 1: Facebook live streaming: The performance of Madurese traditional instrument music in Islamic religious music of Sumenep Ramadhan Festival

Nada FM won the government's trust in organising activities in Sumenep, and eventually became known as a radio event organiser. Every activity involving Nada FM always receives good response from residents as it has many loyal listener bases in Sumenep. These activities, which took place all over the villages in Sumenep and Pamekasan, include healthy society walks, colossal aerobic exercise, the commemoration of Islamic holidays, touring, product launching, music performances, product promotions, seminars, recitals, collaboration with TV for market visits, and Corporate Social Responsibility (CSR) activities such as mass circumcision and compensation for orphans. The challenge as an event organiser is that it requires a big team and resources, from field staff (reporters, broadcasters, technicians) to broadcast technology devices (live broadcast and mobile broadcast equipment). The need to improve the quality of human resources and technology is not negotiable. 
Nada FM also changed the concept of $d a$ 'wah broadcast to serve the high needs of Sumenep's Muslim residents. They have abandoned the traditional broadcasting format of lectures and one-way communication and instead carry out da'wah broadcasts in the following formats: (1) the morning; broadcast recordings of famous Indonesian religious lectures, (2) during the day; local religious leaders (kyai and nyai, ustadz and ustadzah) answer questions from listeners through WhatsApp and comments on Facebook, (3) in the afternoon; a participatory da'wah programme is held where listeners can ask questions directly to local religious leaders according to the theme conveyed at the beginning of the broadcast. In this participatory da'wah, occasionally, it begins with fragments of 2 to 3 announcers, then it is discussed in a participatory manner.

During the da'wah programme in the afternoon and evening, they prioritised conversations using the Madurese language. Madurese language broadcasts receive individual attention by maximising the use of communication technology (ensuring sound quality when broadcasting on-air, via WhatsApp, cell phones, and live streaming on Facebook). Nevertheless, for news and information broadcasts, Nada FM displays the full version on the website and the short version on Twitter.

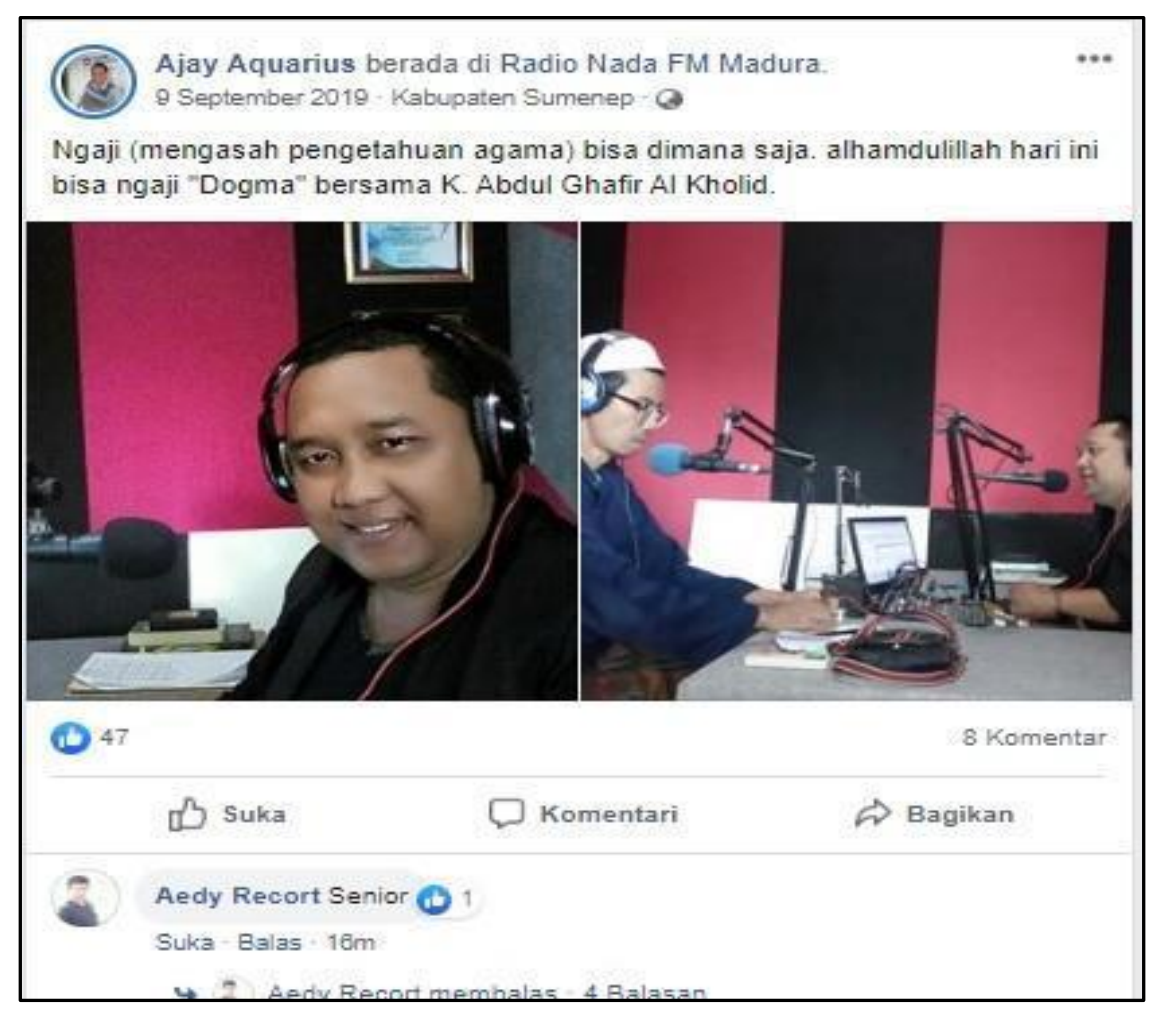

Figure 2: Mr. Ahmad Jailani aka Ajay was having a Facebook live streaming on "Dogma" programme with Kyai Abdul Ghafir Al-Kholid from Pondok Pesantren Salaf Asli Al-Itqon.

One of the best programmes that blend the role of Nada FM as Islamic da'wah radio and Madurese cultural radio is the programme called "Dogma: Dialogue on Religion". Dogma is well-liked by Sumenep residents and surrounding areas because there are many Islamic boarding schools located in Sumenep. Dogma is a radio programme that presents speakers of Islamic religious experts from various Islamic organisations and Islamic boarding schools located in Sumenep and Pamekasan. The broadcasts are thematic, depending on the list of questions from listeners. Producers collect questions from listeners via WhatsApp and Facebook. The theme of the discussion includes Tafsir, Hadith, Nahwu, Sharaf, Tawhid, 
Tasawuf, classical Islamic literature, stories of the prophets, and the Prophet Muhammad's stories and stories of the companions of Prophet Muhammad. Interestingly, all the discussions were delivered in the Sumenep dialect of the Madurese language. Selected speakers deliver answers from Qur'an sources, Hadith, and various significant schools of thought in Islam (Shulhan, 2019). They always avoid justifying only one ulama's view.

For the da'wah programme in the morning, there is a programme called Embun Pagi after Fajr prayer. The Embun Pagi programme is in the form of recorded Islamic lectures from various well-known kyai or ustadz. Some Sumenep residents who are located in urban areas and some eastern Pamekasan residents like Embun Pagi.

Radio Nada FM has a complete Islamic da'wah programme and Madurese culture programme compared to other radios in Madura. Madurese songs and hadrah music with Madurese lyrics synchronise well. Likewise, for news programmes, although there are national morning news broadcasts in two languages, Indonesia and Madurese. The announcers read the news in Indonesian, but casually the news is delivered in Madurese language (Ahmad Jailani, informant 1, programmer).

A popular morning programme is Pangestho Madura (meaning a blessing for Madura), a news programme containing coverage of economic, political, law, and criminal events, family resilience, and various issues in the Sumenep region, delivered in the Sumenep dialect. Nada FM understands the importance of children's moral education for the Sumenep community. The structure of the Islamic Madurese society has similarities with the Malay community in Malaysia, so that they both have concerns about protecting family resilience from threats of the internet and social media (Wok and Abdullah, 2016). For this reason, the delivery of information on Nada FM goes through a filtering process with a gatekeeper and regularly delivers messages about wisdom in social media.

\section{Learning the Madurese Language}

Another programme that portrays a firm grasp of Madurese culture is Tambhana Kaso (meaning relief of fatigue). Interactive broadcasts with various themes relevant to news and viral issues, such as the events of child abduction, terrorism, tobacco growing season, cultural performances, and natural disasters. Listeners can submit suggestions and criticisms according to the theme of the conversation.

Nada FM radio can also be a means of learning to understand the Madurese language. Like Mrs. Riska (informant 2, owner of a shoe and bag care, loyal listener) who is not a native of Madura said:

When I moved to Sumenep in 2005, I could not speak Madurese at all. The move was due to following a father who worked as a civil servant, moving from Bogor. As a teenager at the time, I learned to speak Madurese from school friends. Thank God, there were broadcasts on Nada FM that helped me learn to speak Madurese. Moreover, my school, SMP Negeri 1 Sumenep, is only 200 meters from Nada FM studio on KH. Mansyur. Every time I go home from school, I walk with friends to visit the studio. 
Nada FM once had a specific programme teaching Madurese language called Pamerte Bahasa Madhura. Unfortunately, it only lasted for three years due to a decrease in demand and difficulty getting speakers from the list of Madurese language teachers. The programme was initiated by Ibnu Hajar, H. Imron, and H. Sukkur from the Nabara team (Madurese Language Advisor) of the Sumenep Regency government. They examined the Madurese language in various dimensions, such as its history, language levels, and philosophical teachings.

The Madurese language has similarities with the Javanese language. If the Javanese language recognises three levels, the Madurese language has three to six levels called Ondheggha Bhasa (language levels) (Azhar, 2008; Sofyan, 2010; Stevens, 1965; Zainudin et al., 1978). For those of the same age, the self-reference (one person) is Sengko'. The somewhat older person is Bule, a little old is Kaula, an elder is Abdhina, and the most respectful term is Abdhi Dhalem. When communicating with someone the same age, $B a^{\prime} n a$ (you), is used. One level above it is Dhika. Above it, a little is Sampeyan, above it is Panjenengan, and at the top is Pandhana. The level of language shows respect and appreciation which is the moral value in Madurese culture. Hence, that is the reason why Nada FM may not use the first level Madurese language.

There is a unique programme because it contains $d a^{\prime} w a h$ as well as culture, namely Andhap Asor. This programme contains stories about Madurese social relations based on Islamic Sharia. Madurese have a measure of ethical behaviour in social relationships that is andhap asor (meaning: humble). Andhap asor requires politeness, courtesy, respect, and other noble values that Madurese must possess in line with the teachings of simple living in Islam. For Madurese, they are judging people not by their appearance but rather by looking at their hearts. As the phrase: raddin atena, bhegus tengka gulina (if someone's heart is beautiful, his behaviour must be fair) (Mr. Ibnu Hajar, informant 3, Madurese cultural leader).

There are two programmes on Nada FM that have high selling points to advertisers. The first programme is Dogma (religious dialogue), one of the Islamic da'wah programmes. The second programme is Rhojek Cengor, one of the cultural programmes (Zein \& Dewi, 2019).

Rhojek Cengor is a programme in the form of casual conversation and jokes between 2 or 3 announcers within 2 hours. They usually discuss essential or exciting issues, both locally and nationally, and are of public concern. This programme is broadcasted on Friday afternoon because it contains a summary of various current issues in public for one week. This programme often gets a single sponsor from a private company or government institution. An example of the Rhojek Cengor programme theme is the importance of buying and selling cigarettes with the official excise tax. This programme was sponsored by the Sumenep Regency Government's Economic Service (Merry Rafika, informant 4, announcer). 
Nada FM conveys messages and information using the Madurese language. That is part of its role in maintaining the use of local languages. In other words, Nada FM participates in maintaining and preserving local culture. The courage and consistency of Nada FM in broadcasting using the Madurese language is a cultural reference to Madurese's ethnic identity and an effort to appeal to listeners (Durant \& Lambrou, 2009).

Radio is a media that has a useful role in preserving local languages because radio uses speech-language in its broadcasts. We understand how to pronounce and variations in the language that we do not get in written language through speech. The speech-language is the primary tool in conveying messages from the radio to the listener and strengthens the character of the radio to foster emotional closeness with the listener. The intonation and language variations of the announcer's voice make the message more easily understood by the listener, and eliminate ambiguity (Crisell, 1994). If listeners listened more often to the Madurese language, they could know more than Indonesian, English, or other foreign languages. It shows us the importance of the speech-language role to understand the Madurese language (Murti, 2017). Language style or language variations can be heard from conversations or spoken language, and not from writing. For this reason, radio has a leading role in internalising local language pronunciation.

\section{The Metamorphosis of Nada FM}

The concern and commitment of Nada FM in maintaining and spreading Madura culture are not only limited to broadcasting. Nada FM also voiced Sumenep residents' demands into the political sphere to the regional parliament and the regent's head of the Sumenep region. Some of Sumenep residents' demands that were successfully realised include (1) changes in streets names in the middle of Sumenep city with the names of religious leaders and warrior figures from Sumenep, namely Aria Wiraraja and Sultan Abdurrahman. The naming of those roads was accompanied by writing the Carakan Madurese letter (having similarities with the Javanese letter). And (2) the Madurese language became a local content subject in primary and secondary schools.

Nada FM also facilitates and popularises the growth of Madurese pop, Madurese dangdut, and Madurese koplo music. The distinctive feature of the Madurese instrument lies in the sound of the Saronen (a type of trumpet) (Kunst, 1973; Ruastiti, Vebrian, \& Sariada, 2020), which is always present in all Madurese songs. The types of music most preferred by Nada FM radio listeners are Madurese dangdut, Madurese pop, and Madurese hadrah while koplo is not very popular.

The transition of Nada FM radio to have the identity as a da'wah radio and Madurese cultural radio and the adaptation process of the use of communication technology described in the following mediamorphosis process: 


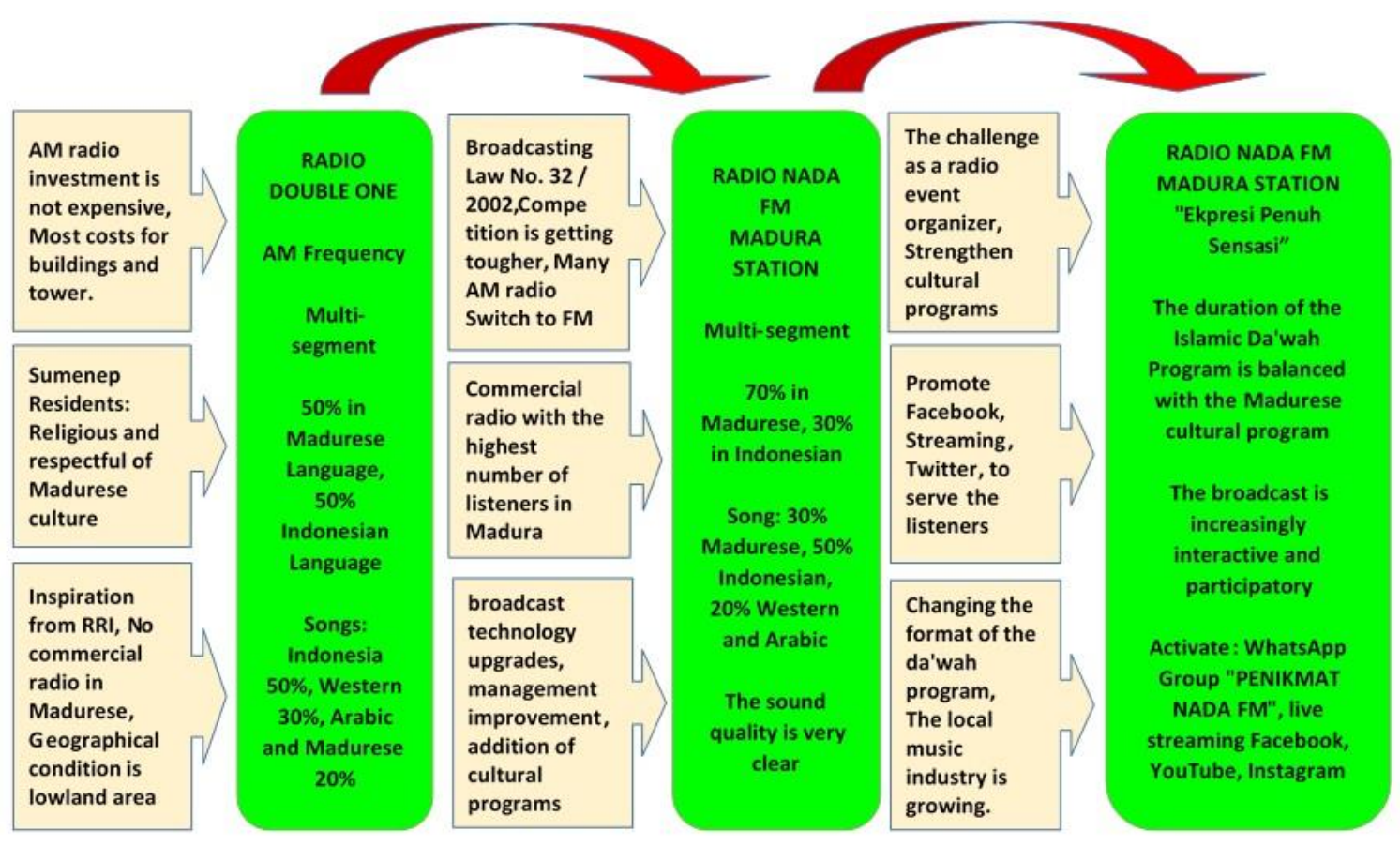

Figure 3: The mediamorphosis process of Nada FM radio

Nada FM enables its Facebook account to support broadcasts and not merely for news or information updates. In 2015-2017, the Facebook account was inactive due to hacking. In April 2017, Nada FM created a new Facebook account and reactivated broadcasts on Facebook until present. Broadcast programmes are regularly updated on Facebook, especially if there is a talk show.

While Nada FM's official website has updated news and other information integrated with a Twitter account, this website always displays the latest issues from local and national. This website provides a streaming facility for listeners abroad, including Hong Kong, Malaysia, and Saudi Arabia. These three countries are the favorite destinations of Indonesian workers (Tenaga Kerja Indonesia) from Madura (Ridwan, informant 5, programmer, and announcer).

The identity of Nada FM as a da'wah radio and Madurese cultural radio was originally an idea proposed by Ibnu Hajar, a Madurese cultural leader who once worked as Double One AM's station manager. But, the history of the Nada FM radio fans' association began with the birth of PERFADA (Persatuan Fans Nada) and had regular activities every month. One of them is gathering through Arisan (rotating savings and loans group). The young listeners of Nada FM radio once formed NADA LOVERS, but it only lasted for a year. Since 2015, Nada FM radio fans have formed a fan group called "Penikmat Nada FM". The same name is used for the WhatsApp group. Nada FM radio listeners use WhatsApp as the primary communication platform because besides being easy to use, most listeners have this application. 


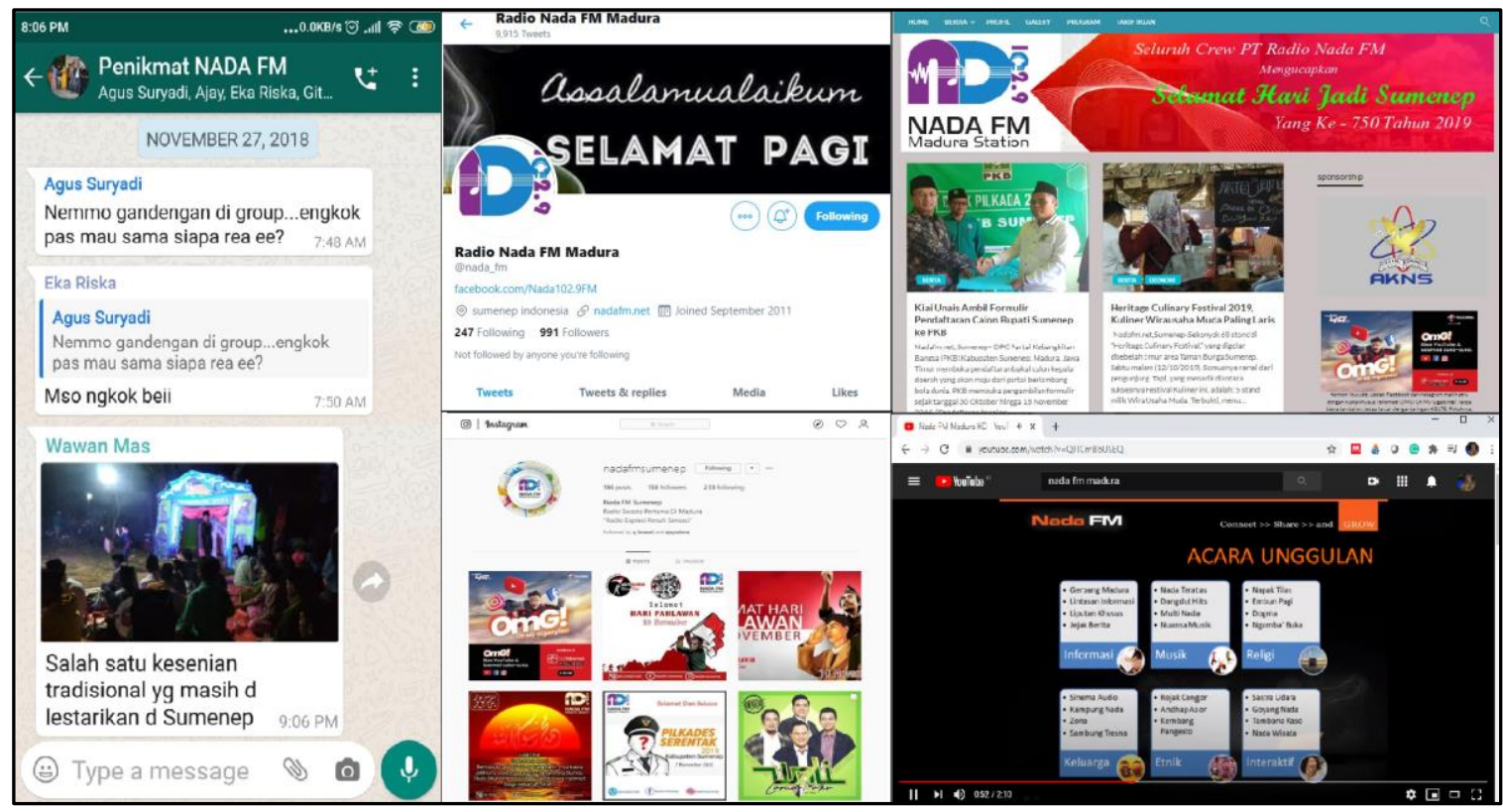

Figure 4: WhatsApp Group, Twitter account, Instagram account, Official website, and YouTube Channel as mediamorphosis broadcast of Nada FM Sumenep radio. These accounts represent broadcasting activities using platforms in Internet network.

While the telephone used for interactive on-air events and is a mainstay of communication media for some listeners with visual impairments, they were very intense in participating in the Dogma (religious dialogue) and Pangestho Madura programme. As stated by Mr. Rikso (informant 6, home industry owner, a loyal listener):

I am only able to communicate with broadcasters only through cell phones. Likewise, some of my workers who have blindness barriers rely on communication with cell phones. If I want to send a short message, my wife helps to type it. If a short message comes in, my wife reads it to me. I can make phone calls to have discussions on the radio. I memorize the locations of letters and numbers on the regular cellphone panel and touch screen cellphone. My cellphone has an FM radio facility so that I can listen to Radio Nada FM broadcasts throughout the day and night. I also have a transistor radio to accompany me and some friends who have visual impairments at work, producing rengginang (traditional Madurese crackers). Even though I am a loyal listener of Radio Nada FM, but I am not active in the WhatsApp group "Penikmat Nada FM" because I cannot operate WhatsApp. Also, my wife is not willing to join the group.

In the WhatsApp group, listeners talk more about health conditions, job vacancies, wedding invitations, study invitations, weather updates, song requests, ask the announcer on duty, solicit casual gatherings, drink coffee together, and to alert announcers (if any wrong info, intonation is not friendly, or excessive jokes).

A strong bond between the listener and Nada FM radio institution forms the listener's loyalty to continue listening to the broadcast even though they have moved to another city. One of them is Mr. Sudap Hafiz (informant 7, area manager for a herbal product, a loyal listener). 
Even though my home and workplace are in Pamekasan, I still listen to Nada FM and actively participate on Facebook during broadcasts and am active in the WhatsApp group. The main reason for my loyalty is the broadcast language factor that uses the Sumenep dialect. Sumenep dialect is more comfortable to be heard and understood by originally born in Sumenep.

Nada FM employees (producers, programmers, and broadcasters) enjoy various benefits due to their close relationship with the listeners, especially financial benefits. They realise that relying on living on a salary is not enough. Listeners provide many side job opportunities, including (1) be a host at various official and entertainment events (weddings, product promotions, Islamic religious celebrations, and cultural shows); (2) become a voice actor for spot advertisements or adlib from local advertisers. The adlib promo usually plays at various celebratory events; (3) become a sound system rental service; (4) become a video and audio editor.

In addition, this study offers several recommendations; (1) encouraging the use of communication technology (streaming, Facebook, WhatsApp, YouTube, and Instagram) at a low cost to support broadcast quality, expand broadcast reach, increase the number of loyal listeners, and increase advertising revenue, (2) motivating radio listeners to have an essential role in the process of producing radio broadcasts, through chat rooms, WhatsApp groups, comments on Facebook and Instagram, (3) collaborating roles between listeners and all workers in the Nada FM radio institution is useful to spread Islamic da'wah and the same time preserve Madura culture and (4) Interacting in the virtual world is an opportunity to expand business networks.

\section{CONCLUSION}

The mediamorphosis process helps support and maintain Nada FM broadcasts, using: streaming application for audio, Facebook for live streaming video, Instagram for updating actual events and famous public figures, WhatsApp for interactive discussion, YouTube, Website, and Twitter for information and news updates.

Nada FM has a very reliable positioning as an Islamic da'wah radio and Madura cultural radio, compared to other radios that broadcast in the Sumenep area. Nada FM is very close to Sumenep residents' hearts because it adopts a synergism of excellence between Islamic religious programme with Madurese culture through complementary broadcast programmes. The Kyai, Nyai, Ustadz, and Ustadzah and caretakers of Islamic boarding schools utilise Nada FM for Islamic da'wah and Madurese cultural leaders and artists use Nada FM radio to promote their artworks. This is in line with the needs of Sumenep residents who need Islamic da'wah programmes but simultaneously still practice the Madurese culture. Therefore, it is evident that the success of Nada FM lies in its ability to strengthen Muslims' beliefs in Sumenep while preserving Madurese culture. 


\section{ACKNOWLEDGEMENT}

This research is a part of a doctoral research project on social science studies in the Faculty of Social Sciences and Political Sciences, Universitas Airlangga, Surabaya-Indonesia. This study is a part of a dissertation titled "Shifting Relationship between Radio Listeners and Radio Institutions in the Network Society (A Virtual Ethnography Study on Cultural Radios in East Java with Mediamorphosis)." This research did not receive any specific grants from funding agencies in the public, commercial, or non-profit sectors. The researchers would like to express their gratitude to the reviewers.

\section{BIODATA}

Zainal Abidin Achmad is a Senior Lecturer in Media and Cultural Studies at the Communication Science Department, Faculty of Social and Political Sciences, Universitas Pembangunan Nasional Veteran Jawa Timur, Indonesia. Email: z.abidinachmad@upnjatim.ac.id

Rachmah Ida is a Professor in Media Studies at the Faculty of Social Sciences and Political Sciences, Universitas Airlangga, Indonesia. Email: rachmah.ida@fisip.unair.ac.id

Mustain is a Professor in Sociology at the Faculty of Social Sciences and Political Sciences, Universitas Airlangga, Indonesia. Email: mustain@fisip.unair.ac.id

Ronald Lukens-Bull is a Professor of Anthropology and Religious Studies at the Department of Sociology, Anthropology, and Social Work, University of North Florida, USA. and Adjunct Professor in the Faculty of Social Sciences and Political Sciences, Universitas Airlangga. Email: ronald.lukens-bull@fulbrightmail.org 


\section{REFERENCES}

Achmad, Z. A. (2019). Integrasi program dakwah dan budaya: Studi etnografi virtual mediamorfosis radio Nada FM Sumenep Madura. Jurnal Komunikasi Islam, 9(2), 238263. https://doi.org/10.15642/iki.2019.9.2.238-263

Achmad, Z. A. (2020). Pergeseran relasi antara pendengar radio dengan institusi radio dalam masyarakat jaringan (Studi etnografi virtual pada radio-radio budaya di Jawa Timur yang bermediamorfosis). Universitas Arilangga.

Achmad, Z. A., \& Alamiyah, S. S. (2015). Relation between political economic of media with the strategies for radio positioning to maintain the existence of commercial radio (Case study of JJFM Radio in Surabaya). International Conference on Democacy and Accountability (ICODA) (pp. 188-193). Surabaya: Faculty of Social Sciences and Political Sciences, Universitas Airlangga.

Achmad, Z. A., \& Ida, R. (2018). Etnografi virtual sebagai teknik pengumpulan data dan metode penelitian. The Journal of Society \& Media, 2(2), 130-145. https://doi.org/10.26740/jsm.v2n2.p130-145

Achmad, Z. A., \& Ida, R. (2019). The shifting role of the listeners in the mediamorphosis process of culture radio: A case study of Jodhipati 106.1 FM. Masyarakat, Kebudayaan dan Politik, 32(3). https://doi.org/10.20473/mkp.v32i32019.240-250

Achmad, Z. A., \& Juwito. (2020). Sritanjung FM: Mediamorfosis dari radioe lare using menjadi kebanggaan Banyuwangi. Penerbit Sahaja.

Achmad, Z. A., Juwito, J., Candrasari, Y., \& Ashfaq, A. (2021). Advantages of implementing mediamorphosis in supporting using-ethnic programs at Radio Sritanjung FM Banyuwangi. Masyarakat, Kebudayaan dan Politik, 3.

Al-hassan, S., Andani, A., \& Abdul-Malik, A. (2011). The role of community radio in livelihood improvement: The case of Simli Radio. Field Actions Science Reports, 5(October 2012), $0-6$.

Alves, R. C. (2001). The future of online journalism: Mediamorphosis or mediacide? Info, 3(1), 63-72. https://doi.org/10.1108/14636690110801815

Azhar, I. N. (2008). Ketika bahasa Madura tidak lagi bersahabat dengan kertas dan tinta. In Efendi, A. (Eds.), Sastra Bahasa dan sastra dalam berbagai perspektif. Yogyakarta: Tiara Wacana.

Baltzis, A. (2004). The Mediamorphosis of the Artistic Communication. Seminar of the European Research Network Digital Radio Cultures in Europe (COST A20), 18. Drace. https://baltzis.webpages.auth.gr/papers/seminar 04 mediamorphosis.pdf

Bappenas RI. (2016). RPJMD Kabupaten Sumenep 2016-2021. RPJMD Kabupaten Sumenep. http://bappeda.sumenepkab.go.id/publikasi/files/RPJMD/RPJMD2016-2018.pdf

Benjamin, W. (2003). Reflections on radio. In M. W. Jennings, G. Smith, \& H. Eiland (Eds.), Walter Benjamin: Selected writings (Vol. 2, pp. 543-544). Cambridge: Belknap Press of Harvard University Press.

Bonini, T., \& Monclús, B. (Eds.) (2015). Radio audiences and participation in the age of network society. New York: Routledge.

Bosch, T. E. (2014). Commercial music radio, race and identity in South Africa. Media, Culture and Society, 36(7), 901-915. https://doi.org/10.1177/0163443714536076

Bouvier, H. (2002). Lebur: Seni musik dan pertunjukan dalam masyarakat Madura. Jakarta: Yayasan Obor Indonesia.

Boyd, A. (2000). Broadcast journalism: Techniques of radio and television news (5th ed.). Oxford: Focal Press. 
Cordeiro, P. (2012). From radio to r@dio: Broadcasting in the 21st century. Conference Proceedings Radio Evolution ECREA 2011 Braga Portugal 14-16 September (pp. 155166). http://www.lasics.uminho.pt/ojs/index.php/radioevolution/825/745

Crisell, A. (1994). Understanding radio (2nd ed.). London: Routledge.

Dia, S. (2003). Radio broadcasting and new information and communication technologies: Uses, challenges and prospects [English translation of the DRAFT paper prepared for the UNRISD Project Information and Communications Technologies and Social Development in Senegal]. UNRISD. https://www.unrisd.org/80256B3C005BCCF9/

Durant, A., \& Lambrou, M. (2009). Language and media: A resource book for students. New York: Routledge.

Ferne, T. (2007). Listener online engagement with BBC Radio programming. London.

Essential Research. (2013). Radio: The listeners' perspective (A research report for Ofcom). Ofcom. https://www.ofcom.org.uk/ data/assets/pdf file/0021/74712/listenersperspective.pdf

Fine, G. A. (2003). Towards a peopled ethnography. Ethnography, 4(1), 41-60. https://doi.org/10.1177/1466138103004001003

Gaynor, N., \& O'Brien, A. (2017). Community radio, democratic participation and the public sphere. Irish Journal of Sociology, 25(1), 29-47. https://doi.org/10.7227/ijs.0002

Geller, V. (2011). Beyond powerful radio: A communicators guide to the internet age. Oxford: Focal Press.

Guest, G., Namey, E. E., \& Mitchell, M. L. (2013). Collecting qualitative data. A field manual for applied research. SAGE Research Methods. https://doi.org/fddb

Hair, N., \& Clark, M. (2003). An enhanced virtual ethnography: The role of critical theory stream 5: Exploring the meaning of 'critique' in electronically-mediated work.

Hine, C. (2000). Virtual ethnography. London: Sage Publications Ltd.

Hine, C. (Ed.). (2005). Virtual methods: Issues in social research on the Internet (1st ed.). Berg: Bloomsburry Publishing.

Hjarvard, S. (2008). The mediatization of society, a theory of the media as agents of social and cultural change. Nordicom Review, 29(2), 105-134.

Johansen, G. (2010). The theater of the mind: A study of radio as an advertising media and the impact of creativity. Copenhagen Business School.

Jurriens, E. (2009). From monologue to dialogue, radio and reform in Indonesia. KITLV Press.

Kasali, R. (1998). Membidik pasar Indonesia: Segmentasi, targeting, dan positioning (P. Utomo, Ed.). Jakarta: Gramedia Pustaka Utama.

KPID Jawa Timur. (2017). Data Lembaga Penyiaran Swasta Radio di Jawa Timur 2017. Surabaya: Komisi Penyiaran Indonesia Daerah Jawa Timur.

Kunst, J. (1973). Music in Java: Its history, its theory and its technique (Vol. II). The Hague: Martinus Nijhoff. https://doi.org/10.1007/978-94-009-3471-9

Kuyucu, M. (2016). The functions of radio and their future in the evolving radio broadcasting. The Journal of Academic Social Science Studies, 43, 221-241. https://doi.org/gizt

Lacey, K. (2013). Listening in the digital age. In J. Lovilglio \& M. Hilmes (Eds.), Radio's new wave: Global sound in the digital era (Section 1: The digital soundscape). Routledge.

Lesscher, L., Lobschat, L., \& Verhoef, P. C. (2021). Do offline and online go hand in hand? Cross-channel and synergy effects of direct mailing and display advertising. International Journal of Research in Marketing. https://doi.org/gjzv

List, D. (2003). Participative marketing for local radio. Wellington: Original Books. 
Loop, M. (1998). Book review of Mediamorphosis: Understanding new media. Mass Communication and Society, 1(1-2), 103-105. https://doi.org/c2b75p

Martín, M. M. (2016). How social media has affected audience's direct participation in Spanish radio stations. The case of the National Radio of Spain. Radio, Sound \& Society, 1(1), 90-99. http://www.ecrea-radioresearch.eu/rss-journal/index.php/view/21

Mohammed, J. (2018). The use of community radio to support local development efforts in Ethiopia: The case of Waghimra Community Radio. Jurnal Komunikasi: Malaysian Journal of Communication, 34(2), 188-204. https://doi.org/gjzw

Murti, F. N. (2017). Pandangan hidup etnis Madura dalam Kejhung Papareghan. Istawa: Jurnal Pendidikan Islam, 2(2), 151-176.

Myers, J. (2009). An independent review of the rules governing local content on commercial radio. http://webarchive.nationalarchives.gov.uk/http:/www.culture.gov.uk/publ.pdf

Nelson-Field, K., \& Riebe, E. (2011). The impact of media fragmentation on audience targeting: An empirical generalisation approach. Journal of Marketing Communications, 17(1), 51-67. https://doi.org/10.1080/13527266.2010.484573

Nguyen, T. T. T. (2008). The role of radio and TV in the life of ethnic minorities in Vietnam: Case study the H'mong people in Lao Cai and Lai Chau province [Master thesis]. University of Troms $\varnothing$.

Norbier, D. (2012). Radio and the Internet: Networked participative radio models. RadioLeituras, III(2), 25-44.

Nugroho, Y., Siregar, M. F., \& Laksmi, S. (2012). Mapping media policy in Indonesia (Report Series - Engaging media, empowering society: Assessing media policy and governance in Indonesia through the lens of citizens' rights). Jakarta: CIPG and HIVOS.

Nwammuo, A. (2011). Mediamorphosis: Analyzing the convergence of digital media forms alongside African traditional media. African Research Review, 5(2), 115-125. https://doi.org/10.4314/afrrev.v5i2.67309

Oliver, R. L. (1999). Whence consumer loyalty? Journal of Marketing, 63, 33-44. https://doi.org/10.2307/1252099

Paisun. (2010). Dinamika Islam kultural: Studi atas dialektika Islam dan budaya lokal Madura. El-Harakah: Jurnal Budaya Islam, 12(2), 154-168. https://doi.org/gi24

Parks, M. R., \& Floyd, K. (1996). Making friends in cyberspace. Journal of Communication, 46(1), 80-97. https://doi.org/10.1111/j.1460-2466.1996.tb01462.x

Priestman, C. (2001). Web radio: Radio production for Internet streaming. Focal Press.

PRSSNI Jatim. (n.d.). Persatuan Radio Siaran Swasta Nasional Indonesia - Jawa Timur > Profil anggota (Retrieved on 29 June 2018). https://www.radiojatim.com/

RadioCentre. (2013). Action stations: The output and impact of commercial radio. https://www.radiocentre.org/files/action stations web.pdf

Radio Nada FM. (n.d.). Facebook. https://www.facebook.com/id=100012074612446

Radio Nada FM. (n.d.). Instagram. https://instagram.com/nadafmsumenep=8sbsbtktsnam

Radio Nada FM. (n.d.). Twitter. https://twitter.com/nada fm?lang=en

Raman, K., \& Naik, P. A. (2004). Long-term profit impact of integrated marketing communications program. Review of Marketing Science, 2(8), 1-21. https://doi.org/10.2202/1546-5616.1014

Rahem, Z., \& Abrari, A. (2019). Perkawinan budaya dan agama pada budaya molang areh masyarakat pedalaman kabupaten Sumenep Madura. Humanistika: Jurnal Keislaman, 5(2), 75-92. https://doi.org/10.36835/humanistika.v5i2.48 
Romeo, C. J., \& Dick, A. R. (2005). The effect of format changes and ownership consolidation on radio station outcomes. Review of Industrial Organization, 27(4), 351-386. https://www.jstor.org/stable/41799267

Ruastiti, N. M., Vebrian, R. E., \& Sariada, I. K. (2020). The inheritance of Saronen instrument in Sumenep, Madura. Humaniora, 11(3), 219-225. https://doi.org/gk25

Sapsford, R., \& Jupp, V. (Eds.). (2006). Data collection and analysis (2nd ed.). SAGE.

Schaap, F. (2002). The words that took us there. ethnography in a virtual reality. Amsterdam: Aksant Academic Publishers.

Schmidt, B. (2012). Interactivity on radio in the Internet age: A case study from France. In S. Gazi, G. Starkey \& Jedrzejewski (Eds.), Radio content in the digital age: The evolution of a sound medium (pp. 28-34). Bristol: Intellect.

Schultz, D. E., Block, M. P., \& Raman, K. (2012). Understanding consumer-created media synergy. Journal of Marketing Communications, 18(3: Cross-Media Effects), 173-187. https://doi.org/10.1080/13527266.2011.567453

Sen, K. (2003). Radio days: Media-politics in Indonesia. The Pacific Review, 16(4), 573-590.

Shulhan. (2019). KH Hafidhi Syarbini dan ijtihad penguatan generasi santri. Rabithah Ma'ahid Islamiyah- Nahdlatul Ulama (RMI-NU).

Siddiq, A., Epafras, L. C., \& Husein, F. (2018). Contesting religion and ethnicity in Madurese society. Religió: Jurnal Studi Agama-Agama, 8(1), 57-81. https://doi.org/gjd

Singarimbun, K., Karlinah, S., Hidayat, D. R., \& Darwis, Y. (2019). The role of celebrity radio DJs in contemporary radio industry: A case study of Prambors network. Jurnal Komunikasi: Malaysian Journal of Communication, 35(3), 57-73. https://doi.org/10.17576/JKMJC2019-3503-04

Sofyan, A. (2010). Fonologi bahasa Madura. Humaniora, 22(2), 207-218.

Stevens, A. M. (1965). Language levels in Madurese. Linguistic Society of America, 41(2), 294302.

Tamimi, M. (2019, May 6). Mengenal asal usul seni musik UI-Daul. Kabarmadura.Id. https://kabarmadura.id/mengenal-asal-usul-seni-musik-ul-daul/

Wok, S., Hashim, J., \& Abdullah, K. (2016). Social media influence on Malay family resilience towards challenges of the Internet. Jurnal Komunikasi: Malaysian Journal of Communication, 32(2), 648-669. https://doi.org/10.17576/JKMJC-2016-3202-32

Zainudin, S., Soegianto, A. K., \& Barijati. (1978). Bahasa Madura. Jakarta: Pusat Pembinaan dan Pengembangan Bahasa, Departemen Pendidikan dan Kebudayaan.

Zein, K., \& Dewi, S. I. (2019). Peran program Rojhek Cingur radio Nada FM dalam melestarikan budaya lokal di Sumenep Madura. Jurnal Komunikasi Nusantara, 1(1), 25-33. https://doi.org/10.33366/ikn.v1i1.7 